\title{
Teletandem as a complex learning environment: Looking for a model
}

\section{Teletandem como ambiente de aprendizagem} complexo: À procura de um modelo

\author{
Annick Rivens MOMPEAN \\ (Université Lille 3, Joint Research Unit STL UMR 8163-CNRS, France) \\ Marco CAPPELLINI \\ (Aix-Marseille Université, Parole\&Langage UMR 7309-CNRS, France)
}

\begin{abstract}
This article presents a model of teletandem, i.e. tandem through desktop videoconferencing (Telles 2009). The aim of such a model is twofold: heuristic and pedagogical. It is heuristic because it enables us to understand teletandem at all its levels and partially to predict (in probabilistic terms) what can happen in a teletandem environment. It is also pedagogical because it helps us formulate plans of action to improve future use and environment design. To build this model, we have drawn upon complexity theory (Larsen-Freeman \& Cameron 2008, Morin 1990), which leads us to distinguish different levels of analysis before discussing the relationship between the different elements and levels leading to the complex final (yet dynamic) model.
\end{abstract}

Key-words: learning environment; teletandem; interactions; modelization; complexity theory. 


\section{RESUMO}

Este artigo apresenta um modelo para o teletandem, i.e., o tandem com o uso de DVC (desktop videoconferencing; cf. Telles, 2009). O modelo aqui proposto tem um duplo objetivo, heurístico e pedagógico. O objetivo heurístico reside no fato de que esse modelo permite compreender o desenvolvimento do teletandem em todos os seus níveis, permitindo, também, prever, parcialmente (em termos de probabilidade), o que pode ocorrer num ambiente de teletandem. Quanto a seu objetivo pedagógico, trata-se do fato de que esse modelo ajuda a definir planos de ação para melhorar o futuro uso e o desenvolvimento de dispositivos pedagógicos dessa natureza. Para a construção desse modelo, referimo-nos à teoria da complexidade (Larsen-Freeman \& Cameron, 2008; Morin, 1990), que permite distinguir, numa perspectiva dinâmica, diferentes níveis de análise, antes de discutir os vínculos entre os diferentes elementos e níveis que levam ao modelo complexo final.

Palavras-chave: Ambiente de aprendizagem; teletandem; interações; modelização; teoria da complexidade.

\section{Introduction}

Our reflection emerged from the observation of the extreme diversity of teletandem configurations, added to the diversity of tandem variations in general (e-tandem, tele-tandem, local tandem) that can exist in university language centers. Tandem is a language learning method where two learners with different mother tongues who study their partner's language, interact in order to help one another in their learning (Brammerts 2002), following the principle of autonomy and reciprocity. The different varieties depend on the environment provided: face to face, by email, or in our study concerning teletandem, desktop videoconference (DVC). The analysis of the way scaffolding (Wood et al. 1976. See section 2.3.2) takes place in teletandem interactions where there is no professional tutor but two learners who in turn play the role of the tutor led us to look for a model, or in other words, to look for recurrent phenomena that may help understand what are the elements that influence the development of teletandem (pedagogical, organizational and political, at macro/meso/micro levels). 
Yet, rather than giving a ready-made model, we will explain the "modelization" process and will focus on the different steps and interactions to be taken into account. Our model is emergent, which means that it is by no means stable and definitive, but will need to be questioned and evolve, depending on the elements in focus, or on the time process (Spear \& Mocker 1981).

We will also discuss the specificity of teletandem interactions themselves and their inclusion in the broader learning environment, basing our analysis on 3 educative levels - macro, meso and microeducative level - in order to fully understand the functioning of teletandem environments. We would like to highlight that the focus on these three different levels does not mean that they are separate and distinct; on the contrary, we will discuss the relationship between the different elements and levels that can help construct a global model of teletandem.

\section{Why looking for a model?}

A model can have a descriptive function in order to find unity through diversity, moving from the local context to the generalization of the results.

\subsection{Finding unity through diversity: starting from the local context}

Our context of observation lies in the language center of Lille 3 University (France), in which teletandem takes place in a self-guided learning environment. Within this specific context, there are different types of tandem settings and different teletandem environments, in different contexts: TTBrasil ${ }^{1}$, TTDL (Dalian Lille) which was the one observed more specifically, TTLeeds, TTAlbright and also TTJL (Japan Lille).

1. Teletandem Brasil: http://www.teletandembrasil.org/home.asp 
There is unity through this diversity, when we refer to the tandem principles which are shared by all tandem environments: autonomy and reciprocity. The autonomy principle (Holec 1981, Little 2002) means that learners are responsible for their learning since they establish contents, decide how to learn and evaluate their learning, therefore taking an active posture in the process. The reciprocity principle (Brammerts 2002) implies that partners have to provide full support to their partner (Salomão et al. 2009). Therefore tandem is a learning method based on communication (Telles 2009) characterized by a didactic communicational contract.

Yet there is diversity when applied to local context, and even amid variety of tandems. The tandem method has first been used in face-toface contexts, but in the mid 90s has been extended to asynchronous written Computer Mediated Communication (CMC) (Brammerts 1996) and synchronous written CMC (Kotter 2003), resulting in what has been called eTandem (O'Rourke 2007). Teletandem is the application of the tandem method to another type of CMC: online multimodal conversation through DVC environments (Telles 2009).

We should add that in our setting, we have a certain flexibility concerning the fact that « languages must not be mixed » (Vassallo \& Telles, 2006: 88), which might be slightly different from other tandem settings. This is due to the fact that previous research (Cappellini \& Zhang 2013) showed that when learners were instructed not to use code switching, long negotiation sequences were encountered in order to find or explain words unknown by the learner. Such long negotiation sequences are not always useful for learning since they generate cognitive overload and a loss of motivation. Moreover, European researchers (for instance Coste et al. 1997) have insisted on the importance of plurilingual competence in foreign language education and exolingual communication.

\subsection{Theoretical references for complex systems}

We will now present the steps towards a model, that can have both a descriptive function, to understand what happens, and a predictive function, to get ready for the predictable elements. This model should 
not be considered as prescriptive, as it is rather a tool to understand the specificities of teletandem, and should not be seen as definitive, as there is no such goal in a dynamic system theory. We refer to the notion of system as expressed by Morin (1990), that takes into account several levels of interactions (relations, actions and reactions), and implies that:

- The whole is greater than the sum of the parts since a macrounity arises at the level of the whole, along with emergent phenomena, new qualities or properties ;

- The whole affects the parts retroactively, while the parts in turn retroactively affect the whole (in other words, the whole has a dynamic organization).

Therefore the levels can be analyzed separately first, but then we need to take into account the relations they have in order to know the parts through the whole and to know the whole through the parts, as described by Morin (1990) for a general system theory based on unitas multiplex.

For that purpose, we will introduce notions from complexity theory such as "configuration" and "attractors". The configuration (also called "state") of a complex system - in our case, teletandem environment - is the dynamic behavior of its elements and their relationship at a given time, as defined by Larsen-Freeman and Cameron (2008: 44).

Referring to the notion of organizing circumstances (Spear and Mocker, 1981) helps to understand how the different elements combine in specific configurations (moments in evolution), as "the details of the specific organization are as varied as the learners and their respective settings. Each learner's circumstances are unique while, at the same time, associated with many standard demographic variables..." (Spear and Mocker, 1981: 6)

The set of all the configurations of the teletandem environment constitutes "the form" of our model, which is transposable to different teletandem environments. In this context, the attractors refer to the most frequent configurations adopted by the system. They are "the content" of our model and they enable us to outline predictions about what could happen in teletandem environments, although they may vary from a teletandem environment to another. In Larsen-Freeman 
and Cameron's words (2008: 49), "in the topological vocabulary of system landscapes, states, or particular modes of behaviors, that the system 'prefers' are called attractors".

\section{Building the model}

In order to start building the model, we can refer to several levels of analysis: at the macro, meso and micro educational levels.

\subsection{Levels of analysis for the teletandem model}

More specifically, when referring to our context, two levels of analysis can be taken into account: the inner level that refers to the teletandem pair itself, that is the place where linguistic interactions take place, and the outer level, that provides a globalizing level of analysis, focusing on the modalities (conditions) for interactions to take place. It includes the relationship of the system with the broader institutional environment, and can be in turn divided into three levels of analysis:

- Macro (at institutional level): what role does the teletandem environment play in the general language learning environment provided by the university?

- Meso (for the organisation of the learning environment): what are the means and aims given to the two institutions? What is the technical support? What are the pedagogical objectives of the teletandem course? Which type of evaluation validates learners' participation to teletandem?

- Micro (at pedagogical level, and where language use takes place): it involves the pedagogical interactions between tutor and learners and between teletandem partners, with some specific questions that can involve:

- Tutor(s)-teletandem partners: what is the role of the tutor? How does (s)he accompany teletandem partners?

- Teletandem partners: how do teletandem partners structure their exchange? How do they position themselves as experts about their cultures and languages? 


\subsection{The outer level}

At the outer level, we can therefore distinguish three levels of analysis or levels of understanding. We will see that the same topic can be seen from different angles, and that the understanding of the existence of these complementary yet sometimes opposed points of view can help understand why, depending on our interlocutor, the level of understanding might not be the same. We might be talking about the same object, yet giving different names to it, or giving different meanings to the same concept (e.g. autonomy that can be seen very differently whether we are on the political and economical side or on the pedagogical side (Rivens Mompean, 2013).

\subsubsection{Macro level}

We distinguish 5 key notions that we consider important to describe and understand what teletandem is about, and that can be associated with different questions, according to the level of analysis. These notions deal with the environment, evaluation, integration, bilaterality and refer to the pedagogical paradigm.

The questions raised at macro level can be formulated as follows:

- Environment: What are the conditions for the use of ICT? Is there any local policy for the technical environment? For example, is Skype allowed? Questions can also concern the physical conditions provided (space, room configuration, whether at home or at university).

- Evaluation: What are the modalities for evaluation: grade or credits?

- Integration: Is teletandem recognized as an institutional practice? Is it integrated into the language learning curriculum?

- Bilaterality: Are the same elements recognized in the same way in both institutions? Is it necessary?

- Pedagogical paradigm: educative and learning cultures, auto vs. hetero recognition. 
As the question of bilaterality is essential in a tandem situation, we duplicate the following questions concerning the setting, as represented in the figure below; yet the answers can be different in each environment. We may wonder whether we need the same answers on both sides so that the teletandem system works efficiently or whether a teletandem program can work well even if the parts have different values.

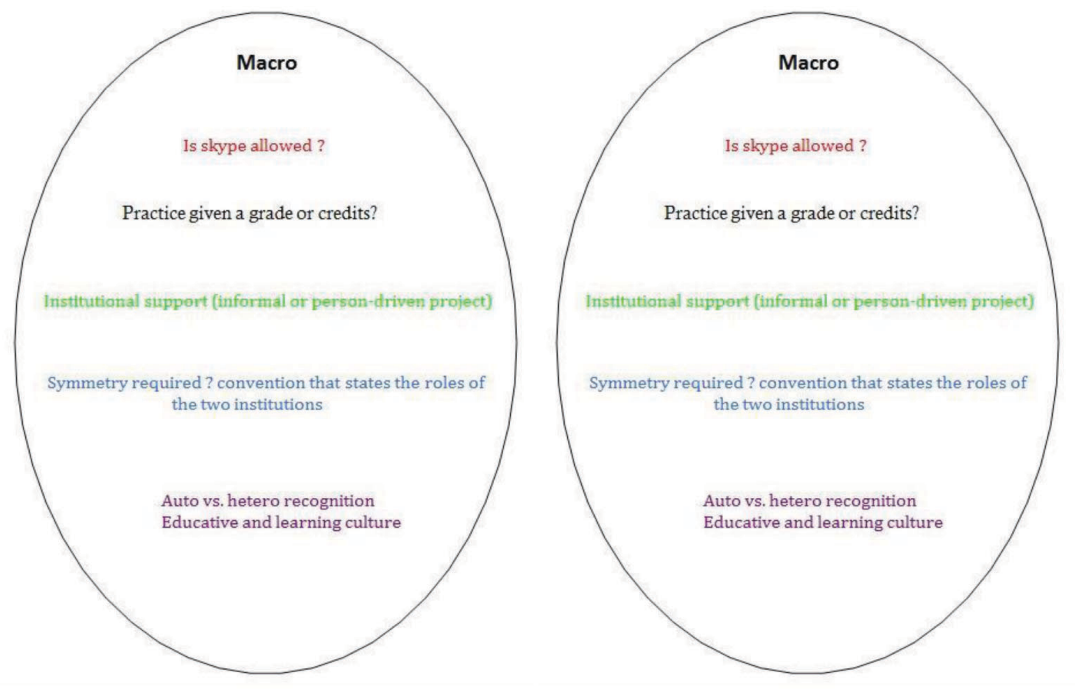

Figure 1 - Macro level analysis of a teletandem setting.

\subsubsection{Meso level}

The questions concerning these 5 same notions will be different at meso level, as described below.

- Environment: What is the technical support required? (Da Rocha, 2009) In which place do the teletandem interactions occur: language center, cybercoffees, at home? What is the impact of the place on the interactions (Marcoccia, 2011)? For example, a conversation taking place at home or at work will have different characteristics: at home partners can show their personal objects. 
- Evaluation: What kind of evaluation can be provided? What are the criteria for assessment?

- Integration: Do we have tutors, counselors, teachers responsible for teletandem in the Language Center?

- Bilaterality: How is teletandem presented to students, by tutors or teachers?

- Pedagogical paradigm: What are the resources provided, referring to both human and pedagogical material.

The meso level is not duplicated as it deals with the whole system, as presented in the following figure.

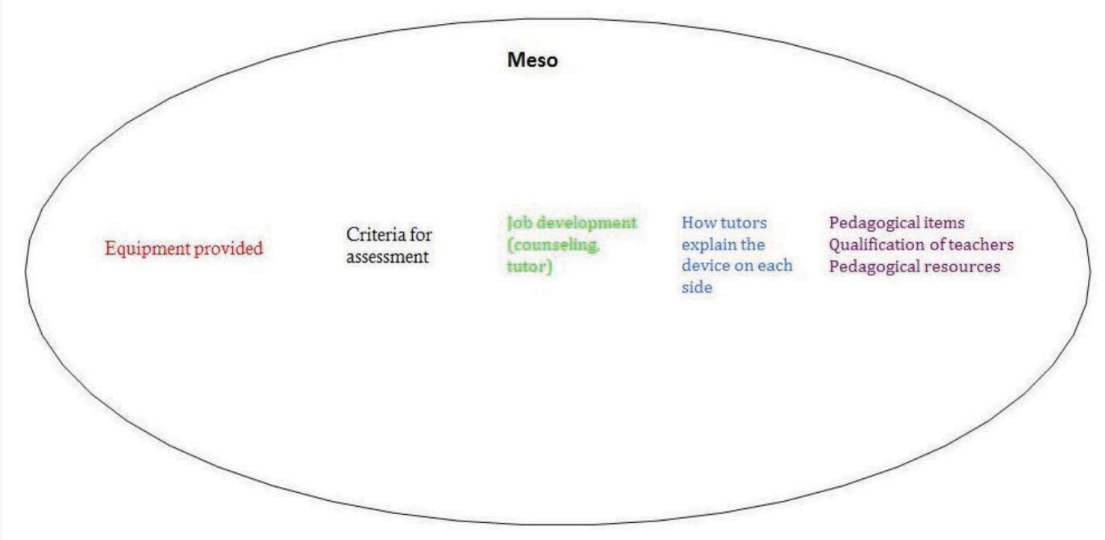

Figure 2 - Meso level analysis of a teletandem setting.

\subsubsection{Micro-level}

The same kind of development can be done at micro-level and the questions are as follows:

- Environment: What are the characteristics of Desktop videoconferencing CMC (Computer Mediated Communication)? 
- Evaluation: What are the items available for evaluation: recording of teletandem sessions, portfolio, final exam (oral interview or self-evaluation)?

- Integration: Which elements of practice are taken into account within a course? Are the teletandem sessions only based on volunteering?

- Bilaterality: What are the different kinds of interaction taking place, both interactions from student to student and interactions between tutors on both sides?

- Pedagogical paradigm: Is there a specific tutor-student(s) relation? What use is made of the learning journal or logbook?

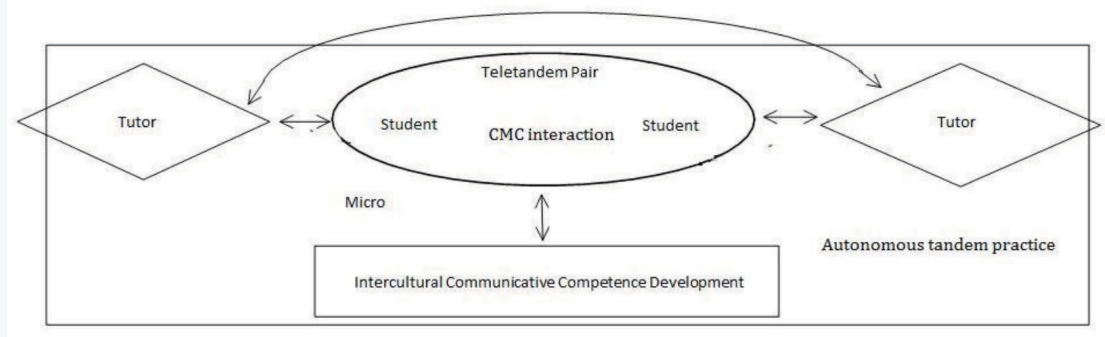

Figure 3 - Micro level analysis of a teletandem setting.

\subsubsection{Global model at the outer level}

Finally putting together the three levels of analysis leads us to the final modelized representation which gathers these different levels, as follows: 


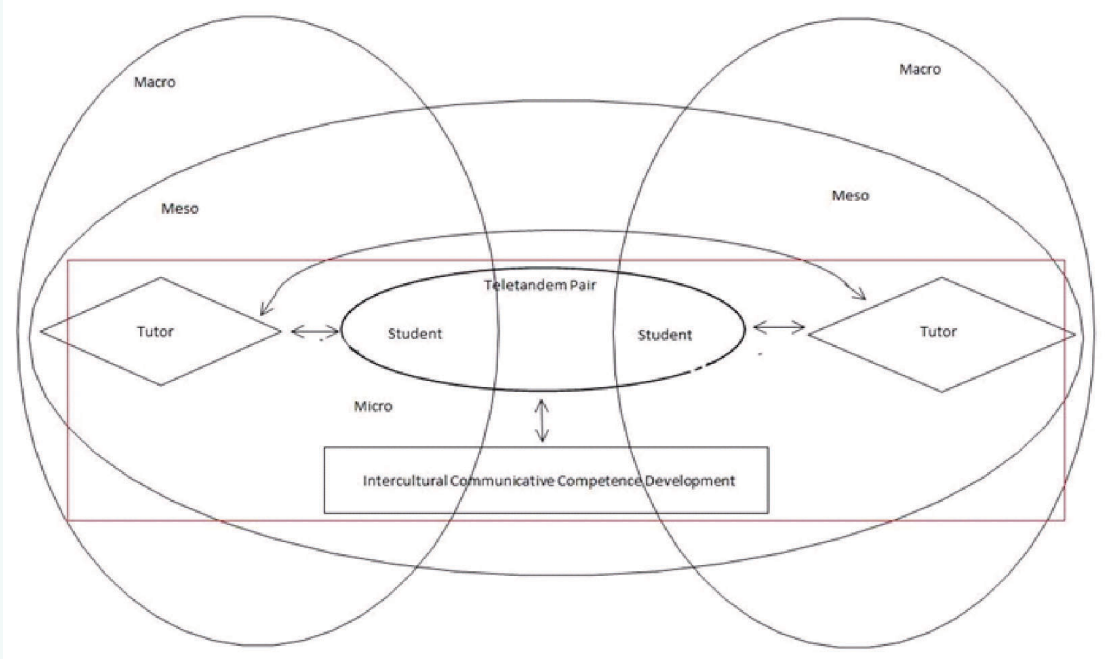

Figure 4 - Complexity of the teletandem setting.

The different questions raised at each level can be summarized in the table below.

Table 1 - Questions raised at each level of analysis

\begin{tabular}{|c|c|c|c|}
\hline & Macro & Meso & Micro \\
\hline Environment & $\begin{array}{l}\text { Is Skype } \\
\text { allowed? }\end{array}$ & Equipment provided & CMC interactions \\
\hline Evaluation & $\begin{array}{l}\text { Practice given a } \\
\text { grade or credits? }\end{array}$ & $\begin{array}{l}\text { Criteria for } \\
\text { assessment }\end{array}$ & $\begin{array}{l}\text { Items possible for } \\
\text { evaluation }\end{array}$ \\
\hline Integration & $\begin{array}{l}\text { Institutional } \\
\text { support }\end{array}$ & $\begin{array}{l}\text { Job development } \\
\text { (counsel, tutor...) }\end{array}$ & Elements of practice \\
\hline Bilaterality & $\begin{array}{l}\text { Symmetry } \\
\text { required? }\end{array}$ & $\begin{array}{l}\text { Explanation provided } \\
\text { on each side }\end{array}$ & $\begin{array}{l}2 \text { learners } \\
\text { Learner/tutor } \\
\text { relationship }\end{array}$ \\
\hline $\begin{array}{l}\text { Pedagogical } \\
\text { paradigm }\end{array}$ & $\begin{array}{l}\text { Auto vs. hetero: } \\
\text { Educative and } \\
\text { learning culture }\end{array}$ & $\begin{array}{l}\text { Pedagogical items: } \\
\text { qualification, } \\
\text { resources... }\end{array}$ & $\begin{array}{l}\text { Autonomous } \\
\text { tandem practice: } \\
\text { role of the tutor }\end{array}$ \\
\hline
\end{tabular}




\subsection{Inner level of analysis}

The inner level of analysis refers to the communication that takes place between teletandem partners. The teletandem pair can be seen as a complex system of its own, related to the other levels of analysis. To study this "micro-system", according to the complex system theory as exposed by Larsen-Freeman and Cameron (2008: 34), we "insist on the connectedness of the social, physical, and cognitive" dimensions. In our model, the social dimension is considered with a focus on the coconstruction of expertise of the partners about the topic of conversation (Cappellini \& Rivens Mompean 2013, 2015); the physical dimension includes both the physical and the digital environments (Cappellini 2014b); the cognitive dimension is studied in terms of scaffolding side sequences, related to language learning (Cappellini 2012, 2014a). First, the social and cognitive dimensions have been studied separately in order to find categories of analysis relevant from a student-perspective, i.e. an emic perspective. Second, the two dimensions were put together to find the possible and actual configurations of the system at the inner level of analysis (the "form" of the model, see above) as well as the attractors (the "content" of the model, see above) (Cappellini, in press). In other studies, the way the social and the cognitive dimensions are connected with the physical dimension is analyzed by Cappellini (2014a, 2014b).

It is important to underscore that adopting a complex approach means to deal with processes and dynamics rather than static entities. Consequently, in our model of the inner level of analysis, the focus is on conversational dynamics of teletandem interactions. More particularly, we draw on the tools of conversation analysis (Dausendschon-Gay 2010, Hall et al. 2011, Sacks et al. 1974 among others) to study how the social dimension is co-constructed locally by interlocutors and how it evolves during conversation. Moreover, we adopt an ecological perspective (Bateson 1972, Bronfenbrenner 1979, Gibson 1979, Van Lier 2004 among others) enabling us to take into account the systemic relations between conversation and environments as well as the manipulation of the environment, especially by students in natural settings, and not laboratory-controlled environment. 
In summary, the questions arising at the inner level of analysis are the following:

- What are the categories of co-construction of expertise about the topic of the conversation and how are they performed through the teletandem environment?

- What are the scaffolding side sequences for language learning and how are they performed through the teletandem environment?

- What are the possible links between the social scaffolding side sequences and expertise about the topic of conversation? In other words, what are the possible configurations?

- What are the attractors?

- Are the attractors relevant for attaining teletandem pedagogical objectives?

To answer these questions, we consider that it is important to analyze the recording of the actual interactions, since they can shed a light on what "really" happens locally in interaction, while the logbooks are more relevant to study students' representations about general dynamics. Therefore our analysis is based on data collected from Cappellini (2014c). We start with a description of our data, then expose the categories of expertise about the topic of conversation and deal with scaffolding side sequences. Then we describe the configurations and attractors at the inner level of analysis before finally considering the possible use of the DVC environment.

\subsubsection{Data collection}

The data we have analyzed were collected within a Sino-French teletandem environment: the Teletandem Dalian-Lille. This environment was designed drawing largely on the research and recommendations of the Teletandem Brazil project. More particularly, data come from two editions: the first one took place between October 2010 and January 2011; the second one between February and May 2012. Students willing to record and give access to their sessions signed an informed consent 
form and received technical instructions about the use of dynamic screen capture and audio recording. Four teletandem pairs ${ }^{2}$ succeeded in recording their sessions (partially or fully). Their proficiency level in their foreign languages ranged from $\mathrm{B} 1+$ to $\mathrm{B} 2$ on the scale of the Common European Framework of Reference (Council of Europe, 2001). The data, which consist in more than 20 hours of recording divided into 15 teletandem sessions, were transcribed and aligned to the recordings using the Eudyco Linguistic ANotator (ELAN). The following table shows the details of our data.

Table 2 - Recording data of Teletandem sessions

\begin{tabular}{|l|c|c|c|}
\hline Teletandem pair & Edition & $\begin{array}{c}\mathbf{N}^{\circ} \text { of recorded } \\
\text { sessions }\end{array}$ & Time length \\
\hline LS & $2010-2011$ & 4 & $7 \mathrm{~h} 30$ \\
\hline AH & 2012 & 3 & $3 \mathrm{~h} 20$ \\
\hline CS & 2012 & 5 & $6 \mathrm{~h} 10$ \\
\hline CW & 2012 & 3 & $3 \mathrm{~h} 20$ \\
\hline Total & & $\mathbf{1 5}$ & $\mathbf{2 0 h 2 0}$ \\
\hline
\end{tabular}

\subsubsection{Expertise postures about the subject of conversation}

In discourse analysis, Chareaudeau (1995) links the notion of role to the communicational contract of a given situation. He distinguishes two components of role: the social role and the communication role. Social role is attributed to an interlocutor by the situation and includes identity, status, age and profession among others. The social role projects onto an interlocutor a set of (communicational) behaviors that can be accepted, negotiated or rejected. However, social role does not determine how a person speaks and what (s)he says. This communication behavior is called "communication role" (hereafter just "role") and is a fully communicational entity. Moreover, Gremmo et al. (1977) identify role with the enactment of rights and duties in 
interaction, which is composed of illocutionary acts and interactive acts (Cappellini \& Rivens Mompean 2015). Since every phenomenon in communication is local and may evolve during interaction (Dausendschon-Gay 2010), our study of role deals with dynamics of role-taking and role-giving throughout teletandem sessions. In particular, we are interested in knowing which roles were enacted according to the topic of conversation, especially cultural topics. In our analysis, we focused on the role of the expert, that is the one who presents him/herself or is presented in interaction as the one who knows and has the right to know and to explain a topic.

Observation of interactions led to identify five types of topic:

1. French topics, that is topics about France or French phenomena such as Christmas in France or the Tour de France (French cycling tour).

2. Chinese topics, that is topics about China or Chinese phenomena such as the Chinese New year or Chinese students' life.

3. Mixed Chinese-French topics. This category was introduced in order to classify sentences of comparison, such as "restaurants in China are louder than in France".

4. Personal topics, that is topics related to one's personal life, such as making a scarf for one's boyfriend or the experience of spending holidays abroad.

5. Other topics, that is topics neither related to personal life nor France and China, such as the football world cup or Hollywood movies.

For French and Chinese topics, we have distinguished five roletaking and role-giving categories. The first and most common one is expert-learner or expert-novice. In this case, the native speaker takes or is given the role of the expert about a topic of her own culture. The second one is expert-expert agreeing, which happens when both interlocutors present themselves as experts about the topic of discussion and the information they bring to the discussion is not contradictory. When the information is contradictory, we have an expert-expert disagreeing role-taking, which is our third category. The fourth category 
is learner-learner or novice-novice. The typical occurrence in this category takes place when an interlocutor asks the other one something about a topic of her interlocutor's culture and the interlocutor does not know the answer. The fifth and final category is a "reverse" expertlearner situation, which happens when the Chinese student takes the role of the expert about a French topic and the French student takes the role of the novice, or vice versa when the French student takes the role of the expert about a Chinese topic and the Chinese student the one of the novice.

As for the other topics (i.e. classified as neither French nor Chinese), the first four categories of role-taking we mentioned are present. The personal topics and the mixed French/Chinese topics lead only to expert-expert role-taking. Table 3 below summarizes our categories.

Table 3 - Categories concerning teletandem role-taking

\begin{tabular}{|l|l|}
\hline Topic & Configuration of role-taking \\
\hline French topic & expert-learner \\
& expert-expert agreeing \\
\hline expert-expert disagreeing \\
\hline learner-learner \\
\hline expert (chn)-learner (fr), i.e. reverse expert-learner \\
\hline Chinese topic & expert-learner \\
\hline expert-expert agreeing \\
\hline Mixed Fr./Ch. Topic & expert-expert disagreeing \\
\hline Personal topic & learner-learner \\
\hline Other topics & expert (fr)-learner (chn), i.e. reverse expert-learner \\
\hline & expert-expert \\
\hline & expert-expert \\
\hline & expert-learner \\
\hline & expert-expert agreeing \\
\hline & expert-expert disagreeing \\
\hline
\end{tabular}


Statistical analysis based on descriptive statistics ${ }^{3}$ shows that the most recurrent role-taking situations are Chinese topic expert-learner, French topic expert-learner and personal topic. In other words, our data confirm a well known phenomenon of tandem learning: the access to the foreign culture is provided almost exclusively by the native speaker. Moreover, the expert role can be expressed through three different positions (Cappellini \& Rivens Mompean 2015): personal, ambassador, expert. When we have a personal position, students refer to the expert using first and second singular pronouns ( $j e$ / 我 and $t u$ /你) in sentences like "I think that French people don't like Japanese cars very much" or "do you believe that Chinese women from the countryside usually have a work?". An ambassador position indicates the use of first and second plural pronouns (nous/我们 and vous/你们) for the expert in sentences like "your cuisine is very different from ours". Finally, an expert position refers to the use of third personal pronouns or to the use of sentences like "in France/China...", which show a detached position from the topic of conversation.

\subsubsection{Scaffolding side sequences}

Scaffolding side sequences are side sequences typical of conversations between a native speaker and a speaker of another language, or exolingual conversations (Porquier 1984). A side sequence (Jefferson 1972) is defined as an interruption of a main sequence about a topic of conversation in order to deal briefly with another topic, in our case about the language spoken. Scaffolding is a notion coming from sociocultural theory (Lantolf \& Thorne 2006) first elaborated by Bruner and his colleagues (Wood et al. 1976) in order to describe how a tutor helps a learner to accomplish a given task. Within sociocultural theory, such an aid is considered as having effects on the development of the learner's competence. In our case, the task consists in accomplishing communication and the tutor is the teletandem partner who is the native speaker.

3. A detailed explanation of the statistical procedures adopted is beyond the scope of this article. For further details about our statistical procedures, see Cappellini (2014c; in press). 
Scaffolding side sequences in teletandem can be defined as different types of side sequences helping the learner to attain successful communication, either in expression or in comprehension. In the Anglo-Saxon literature, these sequences have been studied within the so-called interaction hypothesis (Long 1996) or input-interaction framework (Gass 1997) in terms of negotiations of meaning (Varonis $\&$ Gass 1985). Such an approach is not compatible with a complex system approach, since it is based on a logic of analysis and controlled variables, where one element of a system can be changed without altering the whole system. On the contrary, adopting, as we do, a complex system approach means to consider the links between elements and to postulate that the change of one element can potentially alter the whole system. This is why we turned to the Francophone literature studying exolingual conversation, which adopts a conversation analysis approach compatible with a complex system approach. Among the categories of scaffolding side sequences for language learning, we kept four categories (Cappellini 2014a, 2014c, in press):

1. Sequences of potential acquisition of vocabulary (séquences potentiellement acquisitionnelles lexicales, hereafter SPAlex. De Pietro, Matthey \& Py 1989) are side sequences that happen for instance when the French student is talking in Chinese and she needs some vocabulary to express her ideas. Consequently, she stops and asks for help to her interlocutor, who provides the vocabulary needed.

2. Sequences of potential acquisition of syntax (séquences potentiellement acquisitionnelles syntaxiques, hereafter SPAsyn. Jeanneret \& Py 2002) are almost the same as the previous category but they are related to grammar and syntax. Their conversational structure is slightly different.

3. Sequences of normative evaluation (séquences d'évaluation normative, hereafter SEN. Py 2000). In this case, while the learner is talking in the foreign language, she makes a mistake at some point. Not only does the learner make a mistake, but the language expert also thinks that it needs to be corrected. Then, the expert interrupts the learner's turn and corrects her. 
4. Explicative conversational sequences (séquences conversationnelles explicatives, hereafter SCE. Gulich 1990) are side sequences where during the turn of the language expert, the learner does not understand something and asks for help to attain understanding.

Scaffolding side sequences are a form of mediation (Lantolf $\&$ Thorne 2006), that is a phenomenon of joint attention where the cognition of the learner is somehow external and guided by the interlocutor. Moreover, the learner also guides the interlocutor about her needs, which is a form of "scaffolding of scaffolding" (étayage de l'étayage. Hudelot \& Vasseur 1997. See also Poehner 2008). Consequently, these sequences allow the researcher to formulate hypothesis about learner's cognition and communicative competence development (Cappellini 2012, 2014a).

\subsubsection{Configurations and attractors}

To find the configurations of the teletandem-pair system, we analyzed in which role-taking category scaffolding side sequences took place. Since we are mainly interested in cultural role-taking, we just kept one category of role-taking for the "other topics" category and we did not distinguish between the different kinds of expertise presented in Table 3. Consequently, we have 13 role-taking categories and 8 scaffolding side sequences categories (four for French and four for Chinese), which result in the theoretical possibility of 104 configurations for the teletandem pair system. These configurations are possibly relevant for other teletandem contexts. The graph below shows the possible configurations, that is the "form" of our model at the inner level of analysis. On the x-axis, we have listed the roletaking categories of table 3; on the z-axis we have listed scaffolding side sequences categories and have specified whether they refer to the French language (in which case we put "fr" before the acronym of the category) or to the Chinese language (in which case we put "chn" before the acronym of the category). Each square corresponds to a possible configuration, i.e. a scaffolding side sequence category taking place within a role-taking category. 


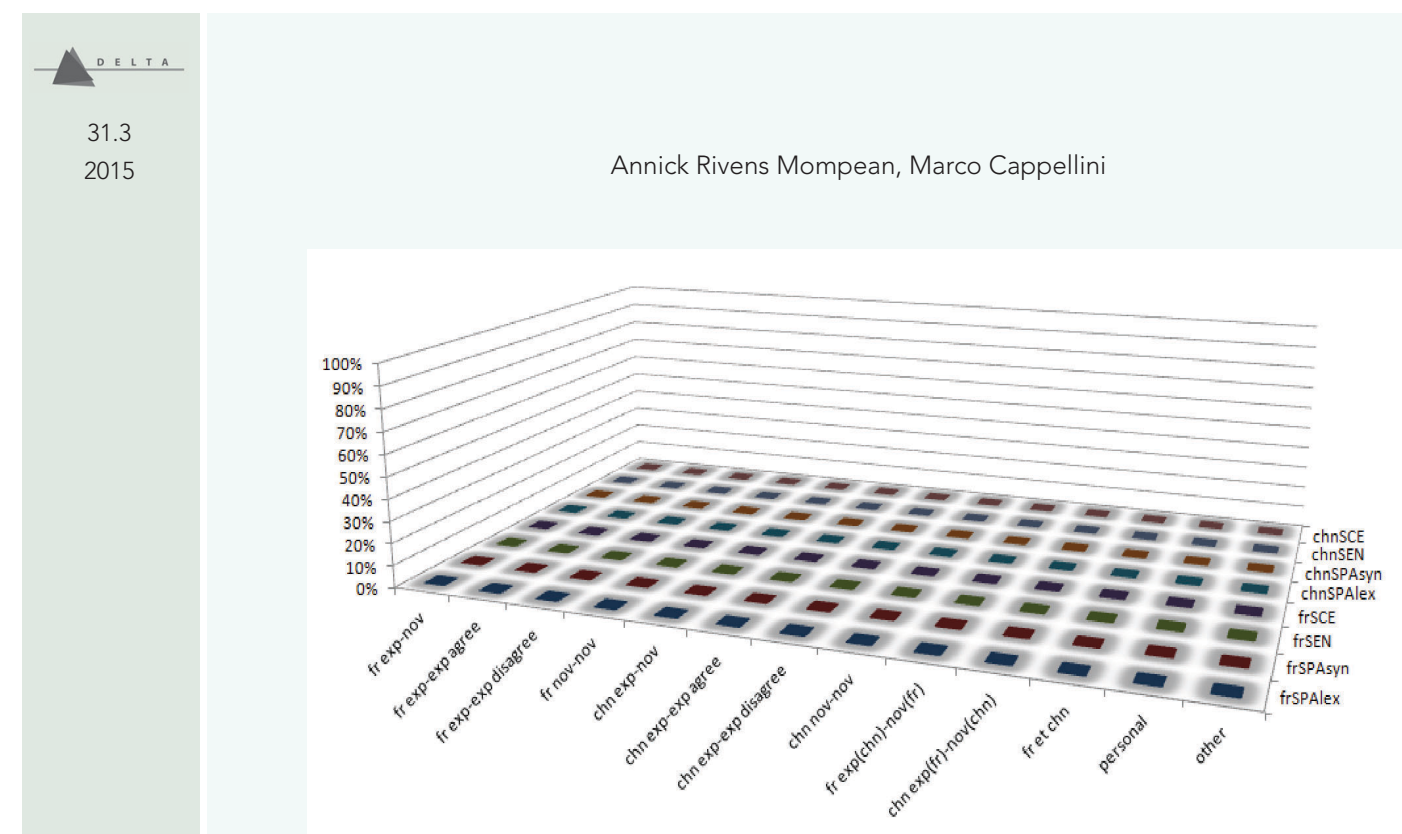

Figure 5 - Possible configurations for teletandem interactions ${ }^{4}$.

After finding these possible configurations, a further step was to calculate the attractors for our corpus. We need to underscore that this statistical analysis could give indications for other teletandem contexts, but that further research is required to prove its relevance. Our results are the "content" of our model at the inner level of analysis. The statistical analysis of our corpus gave the global ${ }^{5}$ results represented in the following graph. The y-axis shows the frequency of occurrence of each configuration. Consequently, the higher the column, the more frequent the configuration:

4. On the x-axis, "fr" means "French topic" and "chn" means "Chinese topic" ; "exp" means "expert" and "nov" means "novice". "fr exp(chn)-nov(fr)" and "chn exp(fr)nov(chn)" indicate the reverse expert-novice configuration for French and Chinese topics respectively. The abbreviations of the $\mathrm{z}$-axis are explained in the previous paragraph. 5. For a more detailed analysis, distinguishing the parts of teletandem interactions in French and in Chinese, see Cappellini (in press). 


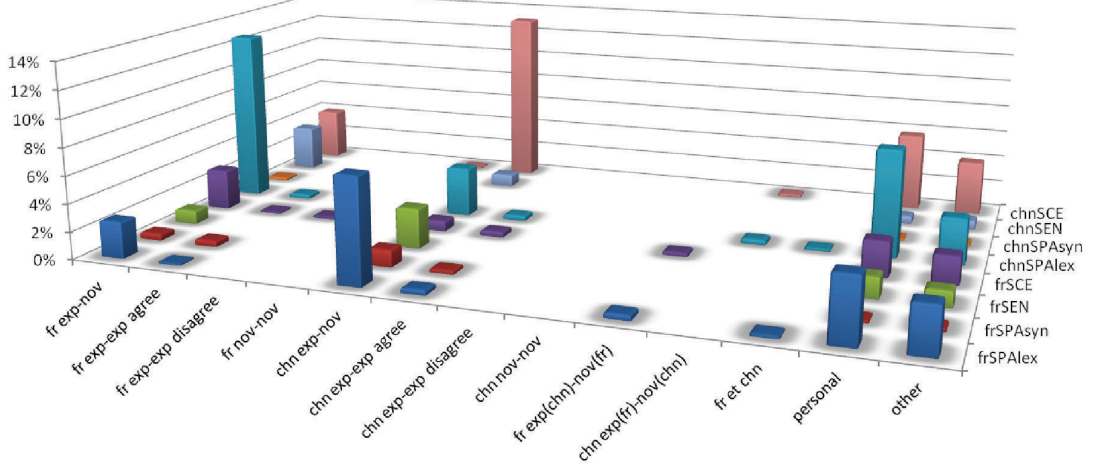

Figure 6 - Actual configurations for teletandem interactions.

In our corpus, attractors are side sequences for the Chinese language (at the back of the graph) more than for the French language, which confirms previous analysis (Cappellini \& Zhang, 2013) The main attractor, that is the most recurrent configuration, refers to conversational explicative sequences for Chinese during a Chinese topic expert-novice role-taking (the tallest pink column). In other words, while the teletandem pair is discussing a Chinese topic and the Chinese student takes the role of the expert, the French student asks a question about the Chinese language in order to understand what her partner says.

The second main attractor refers to potentially acquisitional sequences of vocabulary for Chinese during a French topic expertnovice role-taking (the tallest light blue column). In this case, the French student talks about a French topic in Chinese, taking the role of the expert. While she is talking, she needs some Chinese vocabulary in order to express herself and asks for it to her partner.

The most common attractor for the French language refers to potentially acquisitional sequences of vocabulary during a Chinese topic expert-learner role-taking (the tallest dark blue column), that is when the Chinese learner talks about a Chinese topic in French and asks for some vocabulary. 
Generally speaking, our analysis shows that the four most common attractive role-taking categories are French topic expert-learner, Chinese topic expert-learner, personal topic and "other" topic. Concerning the two first ones, we can identify two general trends. On the one hand, if a learner is talking about her culture in her own language, the interaction will most likely lead to conversational explicative sequences. This dynamics has been named "unilateral expertise", since in this case, both language and cultural expertise are on the same side. On the other hand, if a learner is talking about her own culture in the other's language, interaction will most likely lead to potentially acquisitional sequences of vocabulary. This dynamics has been called "crossed expertise", since one student is the expert about the language used and the other student is the expert about the culture discussed. Crossed expertise seems to be linked to Donato's “collective scaffolding" (1994), which is a type of scaffolding where nobody knows "the right answer" and everybody contributes in order to reach successful expression and understanding. This dynamics could be specific to (tele)tandem interactions.

\subsubsection{The teletandem environment(s) and the role of multimodality}

A final dimension to be taken into account for our model is the environment(s) in which interaction takes place. As any form of telecollaboration, teletandem is characterized by a multiplicity of environments. In fact, interaction takes place through the Internet, which makes Internet-based applications and websites the main environment of communication. Needless to say that the quality of the conversation depends on the interlocutors' Internet connections. Another important distinction is the one made between public space (i.e. school, language center) and private space (one's bedroom), which has an impact on the interaction not only because of the possible interruptions due to other people, but also about the mood of the conversation (Marcoccia 2011): more formal in public space and more friendly in private ones.

Concerning the use of ICT, the first element to be considered is the organization of the screen of both interlocutors (Lamy \& Hampel 2007). This element is important to understand how teletandem partners organize their screens to use at the same time the DVC software and 
possibly other windows, mainly Internet browsers and sometimes folders with images they want to send to their interlocutors. Some teletandem projects also let learners use an interactive online whiteboard.

In order to analyze the use of DVC, we first have to draw a distinction between channel, modality and mode (Drissi 2011). The channel refers to human senses. In DVC communication, the human channels involved are mainly the aural and the visual ones, with the addition of touch in case of manipulation (i.e. use of mouse or keyboard). The modality refers to the DVC software. For instance, Skype allows three main modalities: video, audio and chat. Finally, modes are the semiotic systems mobilized through modalities. For instance, the video modality allows the use of different modes, such as gesture, mimics and proxemics among others. The following table summarizes an analytical view of multimodality distinguishing these three dimensions:

Table 4 - Channels for DVC use

\begin{tabular}{|c|c|c|c|c|}
\hline Channel & \multicolumn{2}{|c|}{ Modality } & \multicolumn{2}{|c|}{ Mode } \\
\hline \multirow{5}{*}{ Aural } & \multirow{5}{*}{ Audio } & \multirow{4}{*}{$\begin{array}{l}\text { Interlocutor- } \\
\text { generated }\end{array}$} & \multirow{4}{*}{ Oral } & Volume \\
\hline & & & & Intonation \\
\hline & & & & Delivery \\
\hline & & & & Pitch \\
\hline & & $\begin{array}{l}\text { System- } \\
\text { generated }\end{array}$ & \multicolumn{2}{|c|}{ Sound } \\
\hline \multirow{12}{*}{ Visual } & \multirow{4}{*}{\multicolumn{2}{|c|}{ Interlocutor's video }} & \multicolumn{2}{|c|}{ Facial expressions } \\
\hline & & & \multicolumn{2}{|c|}{ Gestures } \\
\hline & & & \multicolumn{2}{|c|}{ Proxemics (from screen) } \\
\hline & & & \multicolumn{2}{|c|}{ Showing objects } \\
\hline & \multirow{4}{*}{\multicolumn{2}{|c|}{ Own video }} & \multicolumn{2}{|c|}{ Facial expressions } \\
\hline & & & \multicolumn{2}{|c|}{ Gestures } \\
\hline & & & \multicolumn{2}{|c|}{ Proxemics (from screen) } \\
\hline & & & \multicolumn{2}{|c|}{ Showing objects } \\
\hline & \multirow{3}{*}{\multicolumn{2}{|c|}{ Chat }} & \multicolumn{2}{|c|}{ Written } \\
\hline & & & \multicolumn{2}{|c|}{ Images } \\
\hline & & & \multicolumn{2}{|c|}{ Links } \\
\hline & \multicolumn{2}{|l|}{ Icons } & \multicolumn{2}{|c|}{ Iconic } \\
\hline \multirow{2}{*}{ Environment } & \multicolumn{4}{|c|}{ "Screen" } \\
\hline & \multicolumn{4}{|c|}{ Physical } \\
\hline
\end{tabular}


Drawing from the example of Develotte et al. (2010), we can build a scale of degrees of multimodality in teletandem (Cappellini \& Rivens Mompean 2015). During teletandem interactions, when there is no technical problem, two modalities are always active: audio and video. Therefore, interactions using the audio and video modalities constitute the first degree of multimodality in teletandem interactions. We should note that these two modalities are not completely synchronized (Licoppe \& Relieu 2007), which is a major difference from face-toface communication. When both interlocutors or one interlocutor uses another modality, for instance the chat or an Internet browser, we have the second degree of multimodality. The third degree of multimodality is when two extra modalities different from the audio and video are used at the same time, for instance when an interlocutor searches for information on the Internet and then sends a URL link through the chat.

In our model, the use of DVC multimodality is to be linked with the categories of analysis of role-taking (Cappellini 2014b) and of scaffolding side sequences (Cappellini 2014a). Moreover, the use of multimodality by interlocutors is to be studied through time, in order to analyze possible developments of the multimodal competence (Hauck 2010) by teletandem students (Cappellini 2014a).

\section{What does the model tell us?}

These results can provide useful information with a pedagogical impact. We would also like to insist on the specificities of the model, which should not be considered as neither prescriptive nor definite.

\subsection{The organisation of the system}

First of all, we should insist on the fact that the model is still being built and will certainly evolve. We also need to be aware that if one element changes, the whole system will be affected by that change, in a dynamic perspective. The system appears to be self-organizing, with different ways for the system to organize itself through time, with a coadaptation of the elements of the system and an evolution of 
interactions throughout the exchanges (Larsen-Freeman \&Cameron, 2008: 45). For example, in the interactions analyzed, we have observed a coadaptation of the elements of the system, from the first to the last session concerning code switching, leading to an equilibrium between the languages at the end, while there were more French sequences at the beginning, to shorten the lateral sequences.

The configuration of the system itself depends on different internal and external elements. For example, the way the tutor counsels the teletandem pair may have an influence on the interactions they have online. This is why we consider the pedagogical setting of the utmost importance.

\subsection{How to use the model}

The model can permit a better understanding of the interactions and lead to the building of a pedagogical setting to guide the interactions, in which we can distinguish:

- Proactive counseling: How to prepare the building of the system and anticipate the effects;

- Reactive counseling: Make the partners aware of these postures during feedback sessions.

For instance, according to the characteristic of the macro and meso levels, a tutor could decide to elaborate tasks promoting crossed expertise configurations (proactive counseling). Later, the same tutor could have individual counseling sessions with students to identify issues and suggest conversational topics and/or strategies to improve the student's teletandem experience (reactive counseling). It can also help establish realistic goals such as focus on interactional competence and lexical acquisition, while intercultural goals require narrower guiding and the introduction of group reflective sessions.

The model shows that there are tensions between hetero and selforganization, and that there are choices to be made to structure the material and have a good understanding of what is going on, with a neutral analysis, from a distance facilitated by the research posture. 


\section{Conclusion}

Our model stands at two levels, outer and inner level and at each level, there are some smaller units of analysis to be considered. They need to be analyzed as such, but furthermore they have been combined to be aware of the interactions and retroactions of the elements, in a systemic approach. From the combination of the elements we can see the emergence of a recurrent model, that helps to predict their interinfluence and helps to make the correct pedagogical choices.

Because the model is not just heuristic, it needs to be applied to pedagogical settings to become active (see Section 2 of this issue). A further step will be the observation of the effect of the choices made, in an action-research process, and afterwards, in order to be able to readapt the model in an emergentist approach.

The evolution of technical affordances may require the adaptation of the model as well. From tandem, via etandem to teletandem, there have been obvious changes and whatever the future holds for teletandem interactions, we can be sure that there will be an impact on interactions. Moreover, the development of informal learning through social networks such as Livemocha or Busuu among others (Lamy \& Zourou 2013) networks that offer (sporadic) tandem partners - reactivates the question of pedagogical counseling, especially in language centers. In our opinion, practitioners and researchers in language centers need to position themselves as regards these new phenomena. Should higher education ignore them, integrate them or let students use them outside the institution but give them the reflective tools enabling them to make the most of these environments? In summary, teletandem seems to have left the academic background to enter the everyday life of non academic learners from all over the world and we should pay attention to the kinds of settings that are being developed, and see whether the tandem principles are still applied, and in which conditions, which can be reinterpreted by the model.

Received in March, 2015

Accepted in August, 2015

E-mails:

annick.rivens@univ-lille3.fr marco.cappellini@univ-amu.fr 


\section{References}

Bateson, Gregory. 1972. Steps to an ecology of mind. Chicago: Chicago University Press.

Brammerts, Helmut. 1996. Language learning in tandem using the Internet. In: Mark Warschauer (ed.). Telecollaboration in foreign language learning. Second Language Teaching and Curriculum Center. Honolulu: University of Hawaii Press.

Brammerts, Helmut. 2002. Principes et objectifs. In: Brigitte Helmling. Ed. L'apprentissage autonome des langues en tandem. Paris: Didier.

BRonfenBrenNer, Ulrie. 1979. The Ecology of Human Development. Experiments by nature and design. Cambridge MA: Harvard University Press.

Cappellini, Marco. 2012. Towards a model of scaffoldings during multimodal online interactions in a teletandem environment. In Pre-proceedings of the CMC \& teacher education SIG workshop of Euorcall, Learning through sharing: open resources, open practices, open communication. http://eurocallsigsbologna.weebly.com/ uploads/8/7/4/5/8745414/cappellini_bologna_2012_eurocall.pdf

CAPPellini, Marco. 2014a. Co-construction des routines d'étayage dans un tandem franco-chinois par visioconférence. In: Charlotte Dejean-Thircuir, François Mangenot, Elke Nissen \& Thierry Soubrié (eds.). Actes du colloque Echanger Pour Apprendre en Ligne 2013. http://epal.u-grenoble3.fr/dossier/06_act/pdf/epal2013-cappellini. pdf

Cappellini, Marco. 2014b. Affordances et positionnements d'expertise dans un tandem par visioconférence. In: Isabel Colon de Caravajal \& Magali Ollagnier-Beldame (eds.). Actes du colloque Interactions Multimodales par Ecran 2014. http://impec.ens-lyon.fr/actes-ducolloque-impec-2014-en-ligne-208378.kjsp

Cappellini, Marco. 2014c. Modélisation systémique des étayages dans un environnement de tandem par visioconférence pour le français et le chinois langues étrangères. Une étude interactionniste et écologique du soutien au développement de la compétence de communication. $\mathrm{PhD}$ Thesis in Language Sciences, unpublished.

CAPpellini, Marco. (In press.). Roles and scaffolding in teletandem interactions. Innovation in Language Learning and Teaching, 10.

CAPPEllini, Marco \& Annick Rivens Mompean. 2013. Positionnements culturels dans un tandem sino-français par visioconférence. Synergies Chine 8: 137-149. 
CAPPELlini, Marco \& Annick Rivens Mompean. 2015. Role taking for the teletandem pair involved in multimodal online conversation: some considerations from data to develop counselling practices. Language Learning in Higher Education 5(1): 243-264.

CAPPELlini, Marco \& Meng Zhang. 2013. Etude des feedbacks correctifs dans un tandem par visioconférence. Recherches en Didactique des Langues et Cultures. 10(2): 27-59.

Charaudeau, Patrick. 1995. Rôles sociaux et rôles langagiers. In: Daniel Véronique \& Robert Vion (eds.). Modèles de l'interaction verbale. Aix-en-Provence: Publications de l'Université de Provence.

Council of Europe. 2001. Common European Framework of Reference for Languages. Cambridge: Cambridge University Press.

Coste, Daniel, Danièle Moore \& Geneviève Zarate. 1997. Compétence plurilingue et pluriculturelle. Strasbourg: Editions du Conseil de l'Europe.

Da Rocha, Suzana. 2009. Améliorer l'accompagnement dans les partenariats de teletandem franco- brésiliens. Master 2 DDL FLE, Université Lille 3. http://www.teletandembrasil.org/site/docs/ ROCHA1.pdf

DAUSENDSCHON-GAY, Ulrich. 2010. La construction interactive d'objets. In: Dominique Macaire, Jean-Paul Narcy-Combes \& Henri Portine. Eds. Interrogations épistémologiques en didactique des langues. Paris: Clé International.

De Pietro, Jean-François, Marinette Matthey \& Bernard Py. 1989. Acquisition et contrat didactique : les séquences potentiellement acquisitionnelles dans la conversation exolingue. In : D. Weil \& H. Fugier (eds.). Actes du troisième colloque régional de linguistique. Strasbourg: Université des sciences humaines et Université Louis Pasteur.

Develotte, Christine, Nicolas Guichon \& Caroline Vincent. 2010. The use of webcam for teaching foreign language in a desktop videoconferencing environment. ReCALL 22(3): 293-312.

Donato, Richard. 1994. Collective scaffolding in second language learning. In: James P. Lantolf \& Gabrielle Appel (eds.). Vygotskian Approaches to Second Language Research. Norwood NJ: Ablex.

DRISSI, Samira. 2011. Apprendre à enseigner par visioconférence : étude d'interactions pédagogiques entre futurs enseignants et apprenants de FLE. PhD Thesis, unpublished.

Gass, Susan M. 1997. Input, Interaction, and the Second Language Learner. New York: Routledge. 
GiBson, James Jerome 1979. The Ecological Approach to Visual Perception. London: Lawrence Erlbaum Associates.

Gremmo, Marie-José, Henri Holec \& Philip Riley. 1977. Interactional structure: the role of role. Mélanges pédagogiques 1977. p. 40-56.

Gülich, Elisabeth. 1990. Pour une ethnométhodologie linguistique. Description des séquences conversationnelles explicatives. In: M. Charolles, S. Fisher \& J. Jayez. Eds. Le discours. Représentations et interprétations. Nancy: Presses Universitaires de Nancy.

Hall, Joan Kelly, John Hellermann \& Simona Pekarek Doehler (eds.). 2011. L2 Interactional Competence and Development. Bristol: Multilingual Matters.

Hauck, Mirjam. 2010. Telecollaboration: At the interface between Multimodal and Intercultural Communicative Competence. In: Sarah Guth \& Francesca Helm (eds.). Telecollaboration 2.0. Language, Literacies and Intercultural Learning in the $21^{\text {st }}$ Century. Bern: Peter Lang.

HoLEc, Henri. 1981. Autonomy and foreign language learning. Oxford: Pergamon Press.

Hudelot, Christian \& Marie-Thérèse Vasseur. 1997. Peut-on se passer de la notion d'étayage pour rendre compte de l'élaboration langagière en L1 et en L2 ? Calap 15: 109-135.

JEANNERET, Thérèse \& Bernard Py. 2002. Traitement interactif de structures syntaxiques dans une perspective acquisitionnelle. In: Francine Cicurel \& Georges Daniel Véronique (eds.). Discours, action et appropriation des langues. Paris: PSN.

JefFerson, Gail. 1972. Side Sequences. In: David Sudnow (ed.). Studies in Social Interaction. New York: The Free Press.

KotTer, Markus. 2003. Negotiation of meaning and codeswitching in online tandems. Language Learning and Technology 7(2): 145172.

Lamy, Marie-Noëlle \& Regine Hampel. 2007. Online Communication in Language Learning and Teaching. New York: Palgrave.

Lamy, Marie-Noëlle \& Katerina Zourou (eds.). 2013. Social Networking for Language Education. New York: Palgrave.

Lantolf, James P. \& Steven L. Thorne. 2006. Sociocultural Theory and the Genesis of Second Language Development. Oxford: Oxford University Press.

Larsen-Freeman, Diane \& Lynne Cameron. 2008. Complex Systems and Applied Linguistics. Oxford: Oxford University Press.

LewIs, Tim \& Lesley Walker (eds.). 2003. Autonomous Language Learning in Tandem. Sheffield: Academy Electronic Publications. 
Licoppe, Christian \& Marc Relieu 2007. Présentation. Réseaux 144: 9-23.

LittLe, David \& Helmut Brammerts (eds.). 1996. A Guide to Language Learning in Tandem via the Internet. CLCS Occasional Paper 46.

Long, Michael H. 1996. The role of the linguistic environment in second language acquisition. In: W. Ritchie \& T.K. Bhatia (eds.). Handbook of language acquisition: Vol. 2. Second language acquisition. San Diego, CA: Academic Press.

Marcoccia, Michel. 2011. «T'es où maintenant? " : les espaces de la conversation visiophonique en ligne. In: Christine Develotte, Richard Kern \& marie-Noëlle Lamy (eds.). Décrire la conversation en ligne. Le face à face distanciel. Lyon: ENS Editions.

Morin, Edgar. 1990. Introduction à la pensée complexe. Paris: Seuil.

Poenner, Matthew E. 2008. Both sides of conversation: the interplay between mediation and learner reciprocity in dynamic assessment. In: James P. Lantolf \& Mathew E. Poehner (eds.). Sociocultural Theory and the Teaching of Second Languages. London: Equinox.

Porquier, Rémi. 1984. Communication exolingue et apprentissage des langues. In: Bernard Py (ed.). Acquisition d'une langue étrangère III. Paris: Presses de l'Université Paris VIII Vincennes à Saint-Denis.

Py, Bernard. 2000. La construction interactive de la norme comme pratique et comme représentation. Aile 12: 77-97.

Rivens Mompean, Annick. 2013. Le Centre de Ressources en Langues: vers la modélisation du dispositif d'apprentissage. Villeneuve d'Ascq: Septentrion.

SACKs, Harvey, Emanuel Abraham Schegloff \& Gail Jefferson. 1974. A Simplest Systematics for the Organization of turn-Taking in Conversation. Language 50(4): 696-735.

SAlomão, Ana Cristina Biondo, Andressa Carvalho da Silva \& Fatima De Genova Daniel. 2009. A aprendizagem colaborativa em Tandem: um olhar sobre seus princípios. In: Joao Telles (ed.). Teletandem. Um contexto virtual, autônomo, colaborativo para aprendizagem das linguas estrangeiras no século XXI. Campinas SP: Pontes Editores.

Telles, Joao Antonio (ed.). 2009. Teletandem. Um contexto virtual, autônomo colaborativo para a aprandizagem de línguas estrangeiras no século XXI. Campinas: Pontes.

VAN LIER, Leo. 2004. The Ecology and Semiotics of Language Learning: a Sociocultural Perspective. Dordrecht: Kluwer Academic Publishers.

VARONIS, Evangeline Marlos \& Susan Gass. 1985. Non-native/ non-native conversation. A model for negotiation of meaning. Applied Linguistics 6(1): 71-90. 
Vassallo, Maria Luisa. 2009. Teletandem ou Tandem tele-presencial? In: Joao Telles (ed.). Teletandem. Um contexto virtual, autônomo, colaborativo para aprendizagem das linguas estrangeiras no século XXI. Campinas SP: Pontes Editores.

VASSALlo, Maria Luisa \& Joao Telles. 2006. Foreign language learning in-tandem: Theoretical principles and research perspectives. The ESPecialist 25(1): 1-37.

WooD, David, Jerome S. Bruner \& Gail Ross. 1976. The role of tutoring in problem-solving. Journal of Child Psychology and Psychiatry 17: 89-100. 